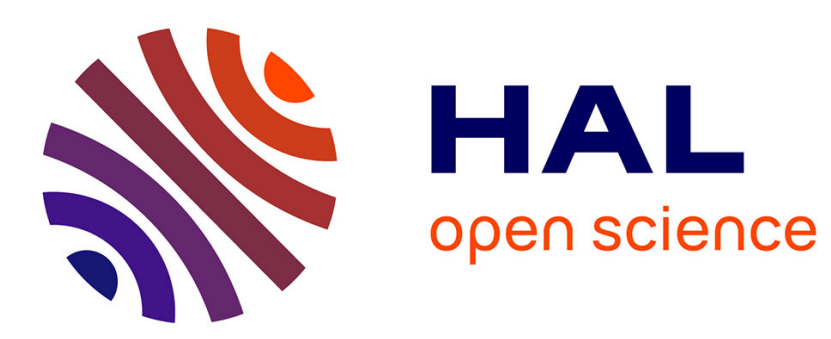

\title{
Aggregation and availability of phosphorus in a Technosol constructed from urban wastes
}

Laure Vidal Beaudet, Sarah Rokia, Thomas Nehls, Christophe Schwartz

\section{To cite this version:}

Laure Vidal Beaudet, Sarah Rokia, Thomas Nehls, Christophe Schwartz. Aggregation and availability of phosphorus in a Technosol constructed from urban wastes. Journal of Soils and Sediments, 2016, 18 (2), 10.1007/s11368-016-1469-3 . hal-01458426

\section{HAL Id: hal-01458426 \\ https://hal.science/hal-01458426}

Submitted on 6 Feb 2017

HAL is a multi-disciplinary open access archive for the deposit and dissemination of scientific research documents, whether they are published or not. The documents may come from teaching and research institutions in France or abroad, or from public or private research centers.
L'archive ouverte pluridisciplinaire HAL, est destinée au dépôt et à la diffusion de documents scientifiques de niveau recherche, publiés ou non, émanant des établissements d'enseignement et de recherche français ou étrangers, des laboratoires publics ou privés. 
Aggregation and availability of phosphorus in a Technosol constructed from urban wastes

\section{Laure Vidal-Beaudet, Sarah Rokia, Thomas Nehls \& Christophe Schwartz}

\section{Journal of Soils and Sediments}

ISSN 1439-0108

J Soils Sediments

DOI 10.1007/s11368-016-1469-3

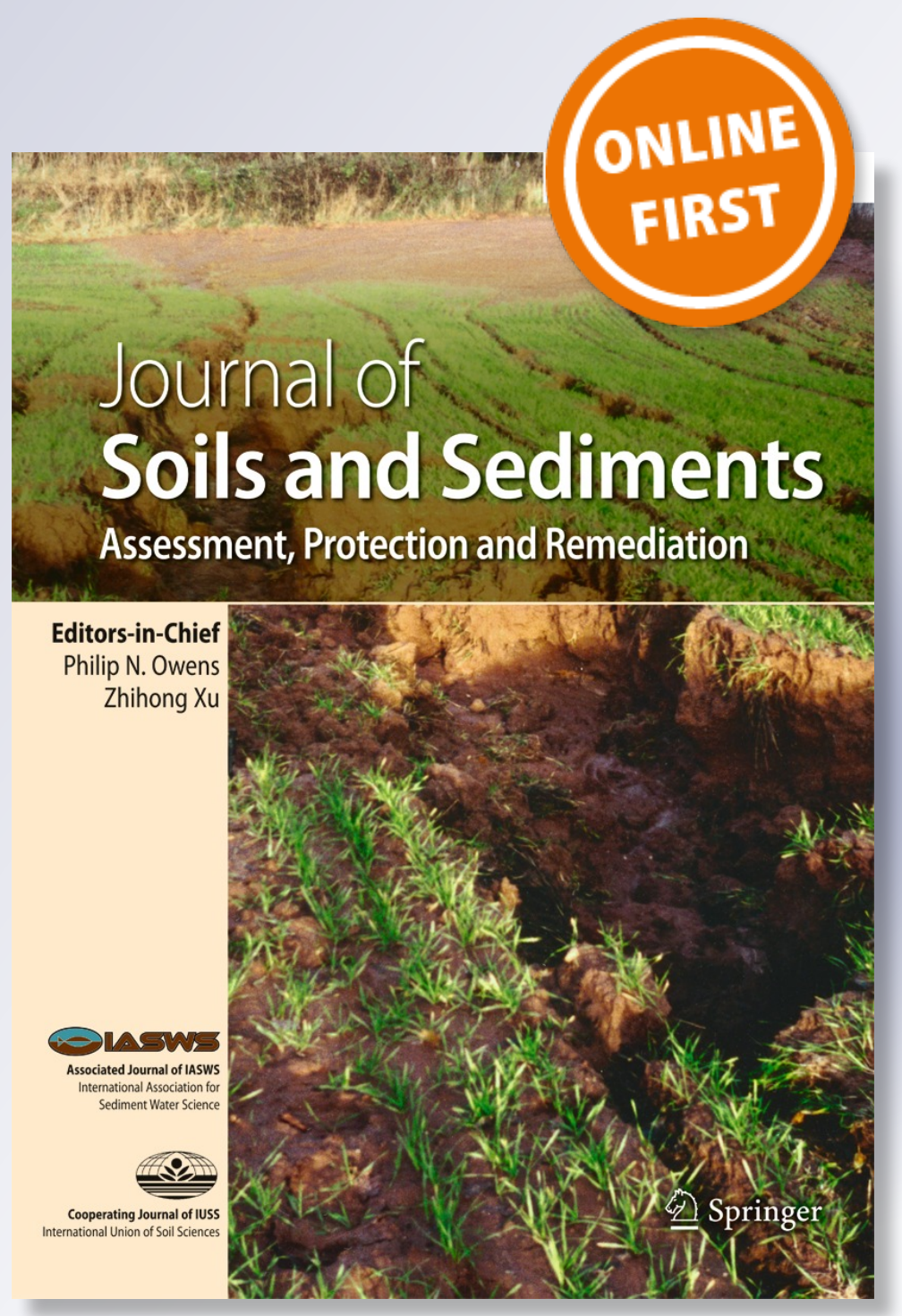

Springer 
Your article is protected by copyright and all rights are held exclusively by SpringerVerlag Berlin Heidelberg. This e-offprint is for personal use only and shall not be selfarchived in electronic repositories. If you wish to self-archive your article, please use the accepted manuscript version for posting on your own website. You may further deposit the accepted manuscript version in any repository, provided it is only made publicly available 12 months after official publication or later and provided acknowledgement is given to the original source of publication and a link is inserted to the published article on Springer's website. The link must be accompanied by the following text: "The final publication is available at link.springer.com". 


\title{
Aggregation and availability of phosphorus in a Technosol constructed from urban wastes
}

\author{
Laure Vidal-Beaudet $^{1,2} \cdot$ Sarah Rokia ${ }^{1,3,4} \cdot$ Thomas Nehls $^{5} \cdot$ Christophe Schwartz $^{3,4}$
}

Received: 28 January 2016 / Accepted: 29 May 2016

(C) Springer-Verlag Berlin Heidelberg 2016

\begin{abstract}
Purpose To preserve natural soil resources and in order to create fertile constructed Technosols for plant cultivation, wastes and by-product mixtures were studied in relation to their pedogenic properties and especially soil organic matter contents. We assessed interactions between aggregation and nutrient availability, focusing on phosphorus $(\mathrm{P})$ transfer in the soil-water-plant system.

Materials and methods Four typical urban wastes, dried and sieved to pass $2 \mathrm{~mm}$, were mixed selectively to mimic a fertile topsoil material: excavated subsoil AE, compost from sludge and green wastes $\mathrm{CO}$, green wastes $\mathrm{GW}$, and bricks BR. After characterization of the wastes for physico-chemical and toxicological parameters, we focused on four mixtures: $\mathrm{AE} / \mathrm{CO}$, $\mathrm{AE} / \mathrm{GW}, \mathrm{BR} / \mathrm{CO}$, and $\mathrm{BR} / \mathrm{GW}$. The mixtures were tested in a 55-day long pot experiment under controlled conditions in a climate chamber. Pots were bare and planted with Lolium perenne (ryegrass) and Brassica napus (rape). The two plant species were selected for contrasting root activities and
\end{abstract}

Responsible editor: Maxine J. Levin

Laure Vidal-Beaudet

laure.beaudet@agrocampus-ouest.fr

1 Environnement Physique de la Plante Horticole, Centre d'Angers, Agrocampus Ouest, 49045 Angers, France

2 IRSTV-FR CNRS 2488, Ecole Centrale de Nantes, 44321 Nantes, France

3 Laboratoire Sols et Environnement, Université de Lorraine, UMR 1120, 54518 Vandœuvre-lès-Nancy, France

4 Laboratoire Sols et Environnement, UMR 1120, INRA, 54518 Vandœuvre-lès-Nancy, France

5 Technische Universität Berlin, FG Standorkunde und Bodenschutz, 10587 Berlin, Germany architectures and phosphorus (P) acquisition strategies. The aggregate formation was tested using the mean weight diameter method at the end of the experiment.

Results and discussion We have measured intense aggregation in mixture $\mathrm{AE} / \mathrm{GW}$, low aggregation in $\mathrm{AE} / \mathrm{CO}$, and no aggregation in $\mathrm{BR} / \mathrm{CO}$ and $\mathrm{BR} / \mathrm{GW}$. After 55 days, neither Technosol aggregation nor aggregate stability was significantly affected by plant development. Available phosphorus $\left(\mathrm{P}_{\text {Olsen }}\right)$ content was sufficient for plant development in all the mixtures (from 0.28 to $0.58 \mathrm{~g} \mathrm{~kg}^{-1}$ ). The $\mathrm{P}_{\mathrm{Olsen}} / \mathrm{P}_{\text {total }}$ ratio was higher in mixtures with $\mathrm{GW}$, even if the mixtures with compost $(\mathrm{AE} / \mathrm{CO}$ and $\mathrm{BR} / \mathrm{CO})$ induced the highest biomass production for ryegrass and rape.

Conclusions The nutrient availability in constructed Technosols and the transfer of $\mathrm{P}$ to plant were highly dependent on organic matter type, with high or low delivery of $\mathrm{P}_{\text {Olsen }}$ linked to the mineralization potential and the size and distribution of aggregates. Therefore, pedological engineering processes can be improved by the selection of adapted constitutive wastes and byproducts to create a fertile substrate allowing high biomass production.

Keywords Aggregation · Available phosphorus · Plant biomass $\cdot$ Technosol $\cdot$ Waste

\section{Introduction}

Urban greening including urban gardening has recently been discussed as an effective measure to improve the living circumstances of the city dwellers and the ecological resilience of the city. The numerous ecosystem services of urban greening have been extensively discussed (Morel et al. 2015). Pedological engineering has then proposed mixing technogenic materials in order to create fertile organo- 
mineral constructed Technosols for the greening of cities and subsequently for the biomass production in cities (Nehls et al. 2015). Construction of soils or plant substrates from urban wastes and industrial by-products presents a high potential to reuse and to recycle nutrients. It enables to reduce the dependency from mineral fertilizers to sustain at first vegetated green space. Constructed soils could even be a support in future urban agriculture for food production in the city.

This is important as after more than half a century of the widespread application of $\mathrm{P}$ fertilizers in agriculture, the global P resource is progressively depleting (Cordell et al. 2009). The risk of lower yields due to $P$ deficiency exists and entails a need for the development of P-recycling strategies. Mainly, organic materials have been studied regarding their fertilizing potential (Jimenez 1993; Nziguheba 1998; Johnson et al. 2004). However, a wide range of urban and industrial wastes can be potentially recycled to Technosols and can thus form an important source of $\mathrm{P}$ for plants. Nevertheless, the phytoavailability of $\mathrm{P}$ is depending on physical fertility of constructed soil and especially on soil aggregation. The effects of factors of pedogenesis (original material, climate, time, biological activity, anthropogenic impacts) on pedological processes (e.g., aggregation, leaching, podzolization) and the evolution of the physico-chemical properties of constructed Technosols should then be investigated. Two very important characteristics of such a planting substrate are (i) the formation and stability of aggregates and (ii) the nutrient availability as both parameters describe soil fertility. The main aggregation processes are (1) swelling and shrinking leading to new regulation of primary particles and to compaction; (2) biological aggregation due to gluing substances (worms, microorganisms, fungi, root exudates) (Chenu and Cosentino 2011); or (3) multivalent cations which bridge particles together depending on $\mathrm{pH}$.

It is difficult to predict aggregation and formation of those organo-mineral associations when mixing two technogenic materials together. It is even less obvious to predict the stability of such associations in the substrate. This is because formation, functioning, and evolution of Technosols are strongly influenced by the characteristics of technogenic materials, which are mostly unknown. In their work, Monsérié et al. (2009) demonstrated the presence of newly formed stable technogenic microaggregates $(2-200 \mu \mathrm{m})$ in coking plant wastes. Séré et al. (2010) studied the properties of a Technosol constructed from wastes and revealed the presence of stable aggregates of papermill sludge by-products before they are mixed with other materials (thermally treated industrial soil and green waste compost). Jangorzo et al. (2013) quantified the aggregation of Technosols in the early stages of pedogenesis and showed the positive impact of factors such as fauna activity and root development. However, the aggregation process of Technosols is strongly related to the addition of organic materials capable of interacting with inorganic particles allowing a long-term stabilization of aggregates (Jastrow 1996; Angers et al. 1999; Chenu et al. 2000; Grosbellet et al. 2011).

Technosols are considered to be "young" soils in the sense that they show a high chemical reactivity (Lehmann and Stahr 2007). Some Technosols developed on wastes from steel industry have been studied in relation to the mobility of metals in the environment (El Khalil et al. 2008; Badin et al. 2009; Huot 2013), but very few works have studied the fertility and the ability of a Technosol to support plant growth (Pey 2010; Séré et al. 2010). Knowledge of the mechanisms that will predominate in terms of chemical reactivity in constructed soils remains unresolved, as does that of their impact on the release of P in solution. By including large amounts of organic matter, constructed Technosols constitute a reservoir of nutrients for plants and microorganisms. Some mineral artifacts such as bricks are quite stable in the soil and do not seem to participate strongly in the chemical reactivity of the resulting Technosols (Nehls et al. 2013). However, chemical weathering of mineral wastes seems to be dependent on their fragment size and porosity (Howard and Olszewska 2011). The chemical fertility of constructed Technosols is then controlled by the chemical weathering process in organic and inorganic components that allows the transfer of nutrients such as P. Phosphorus availability in substrates built up from wastes is little known, and a case-by-case study of the effect of selected wastes on the soil properties is needed (Jimenez 1993; Johnson et al. 2004).

The factors that mainly control the immobilization or mineralization of $\mathrm{P}$ in the soil are vegetation, microbial biomass, soil fauna, and soil properties such as $\mathrm{pH}$ or porosity (Hinsinger 2001; Frossard et al. 2004). The $P$ transformation processes are highly dependent on the stability of the organic matter and thus on the physical stabilization of its aggregates. In fact, at least $50 \%$ of $P$ contained in composts is in mineral forms (Frossard et al. 2002) and only orthophosphate ions are taken up by the plants directly either via the roots or via mycorrhizal fungi (Rausch and Bucher 2002). Roots have a major influence on soil formation and aggregation (Tisdall and Oades 1982), and Barber and Silberbush (1984) showed that $P$ uptake is controlled by morphology and root activity. Rape develops a specific strategy for P mobilization through its roots (Grinsted et al. 1982; Hedley et al. 1983; Hoffland et al. 1989).

A national research program funded by the French Environmental Agency (SITERRE-ADEME research program) is dedicated to the development of pedological engineering for the construction of soils in urban areas. During this program, 11 wastes were selected from the European Waste Catalogue (European Commission no. 94/3/CEE, 1993). Rokia et al. (2014) studied the agronomic properties of waste mixtures resulting from soil construction processes. The laboratory fertility of the new substrates obtained from 
mixing of wastes was modeled by multilinear regressions for the main soil properties.

The aims of the present study are to investigate the feasibility of the construction of fertile Technosols in relation with their pedogenic properties and especially soil organic matter contents. The main hypothesis is that nutrient delivery and transfer in Technosols are highly dependent on organic matter nature and linked to mineralization potential. Our objectives are to assess interactions between pedogenic processes including aggregation and nutrient (e.g., phosphorus) availability and transfer in the soil-water-plant system. To test our hypothesis, we described the physico-chemical fertility of four selected mixtures of mineral and organic wastes in the early stages following soil construction. Fertility, aggregation, and nutrient availability of $\mathrm{P}$ were measured in the constructed Technosols over 55 days in a pot experiment.

\section{Materials and methods}

\subsection{Wastes and mixture characteristics}

Rokia et al. (2014) investigated 11 contrasting urban wastes and tested 25 binary or ternary mixtures of these wastes for their potential to serve as plant substrates. They proposed to further investigate substrates constructed from four typical urban wastes: two composts, one made out of a mixture of sludge and green wastes (CO) and one made out of green waste only (GW), and two mineral wastes, excavated acidic earth material (AE) and bricks (BR). Those were selected to mimic a fertile topsoil substrate when mixed in appropriate combinations. Selected chemical and physical properties of the four wastes were characterized (Table 1). Green waste compost brought in large quantities $(40 \% v / v)$ showed a breakdown of its organic particles that protected aggregates from degradation and modified soil pore distribution (Grosbellet et al. 2011). The compost influenced physical properties such as porosity, bulk density, or the water holding capacity of constructed technosols. The material AE with its acidic $\mathrm{pH}$ is the only material capable of adjusting the high $\mathrm{pH}$ usually found in organic wastes, for optimum plant growth. Bricks were shown to be appropriate substitutes for earthy materials due to their internal porosity and their contribution to the nutrient stock (e.g., $\mathrm{K}, \mathrm{Mg}, \mathrm{Ca}$, and S) (Nehls et al. 2013). In addition to waste mixtures, an agricultural soil of known agronomic properties (sandy loam soil) was selected as a control (Table 1).

The four waste materials and the control soil were air-dried, crushed in order to increase the surface area between particles, and sieved to pass $2 \mathrm{~mm}$ before mixing. The wastes have been moistened at $80 \% \mathrm{w} / \mathrm{w}$ of their water field capacity $(-10 \mathrm{kPa})$. They have been weighed, mixed, and homogenized manually for $5 \mathrm{~min}$. We have focused on four mixtures (AE/CO, AE/
GW, BR/CO, BR/GW) selected for their ability to support plant biomass production with ratio $75 / 25 w / w$ for $\mathrm{AE} / \mathrm{CO}$ and $\mathrm{AE} / \mathrm{GW}$ and 50/50 $w / w$ for $\mathrm{BR} / \mathrm{CO}$ and $\mathrm{BR} / \mathrm{GW}$ (Rokia et al. 2014).

\subsection{Experimental design}

Waste mixtures were placed in $2-1$ square pots $(13 \times 13 \times$ $12.5 \mathrm{~cm}$ ) drained at the bottom by a $1-\mathrm{cm}$ gravel layer. For the same volume, the dry mass and the bulk density in the pot depend on mixture type and were determined by the laboratory method EN 13040 (CEN 1999). Values were $1.2 \mathrm{~kg}$ and $0.6 \mathrm{~g} \mathrm{~cm}^{-3}$ for BR/GW, $1.8 \mathrm{~kg}$ and $0.9 \mathrm{~g} \mathrm{~cm}^{-3}$ for $\mathrm{AE} / \mathrm{GW}$, and $2 \mathrm{~kg}$ and $1 \mathrm{~g} \mathrm{~cm}^{-3}$ for $\mathrm{AE} / \mathrm{CO}$ and $\mathrm{BR} / \mathrm{CO}$. The mixtures were not fertilized. The sandy loam soil used as control soil had a bulk density of $1.4 \mathrm{~g} \mathrm{~cm}^{-3}$, and the dry mass placed in the pot was $2.8 \mathrm{~kg}$. Two plant species were selected for their contrasting root activities and architectures: Lolium perenne (ryegrass), which has a fasciculate root system, and Brassica napus (rape), which has a taproot system. The seeds (1 g of seeds per pot for ryegrass and 12 seeds per pot for rape, 1 plant being retained after germination) were sown ( $\mathrm{t} 0$ ) on the mixtures and the control soil. They were cultivated for 55 days (t55) in controlled conditions in a climate chamber: $16 \mathrm{~h}$ of daylight at $21^{\circ} \mathrm{C}$ and $8 \mathrm{~h}$ of night at $18{ }^{\circ} \mathrm{C}$, at a light intensity of $400 \mu \mathrm{E} \mathrm{m}^{-2} \mathrm{~s}^{-1}$, and a relative air humidity of $70 \%$. Capillary irrigation was used to keep the substrates at constant soil moisture of $80 \%$ of the water content at a suction of $-10 \mathrm{kPa}$.

The effect of three treatments - (a) the four mixtures and the control soil with no plant, namely, bare soil (BS), (b) the four mixtures and the control soil sown with ryegrass (RG), and (c) the four mixtures and the control soil sown with rape (RA) - was tested for four replicates on each substrate resulting in 60 pots. They were arranged in a randomized complete block design. Aerial parts of the two plant species were harvested only at the end of the growth experiment, even if 55 days is long for a ryegrass sward. Plants were washed with tap water and weighed before and after drying at $70{ }^{\circ} \mathrm{C}$ for $48 \mathrm{~h}$.

\subsection{Assessment of aggregate formation and structural stability}

The structural stability was measured on macroaggregates as described by Le Bissonnais (1996). Samples from each treatment were air-dried and were sieved to collect macroaggregates whose size ranged from 3 to $5 \mathrm{~mm}$. These aggregates were maintained in a ventilated oven at $40{ }^{\circ} \mathrm{C}$ for $48 \mathrm{~h}$ before being analyzed. The analysis consisted of three series of tests to assess the resistance of aggregates to various breakdown mechanisms: fast and slow wetting tests to assess the resistance to slaking and microcracking, respectively, and the 
Table 1 Chemical and physical properties of the four wastes selected, the control soil, and the four waste mixtures supposed to be fertile

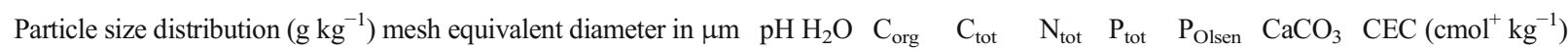

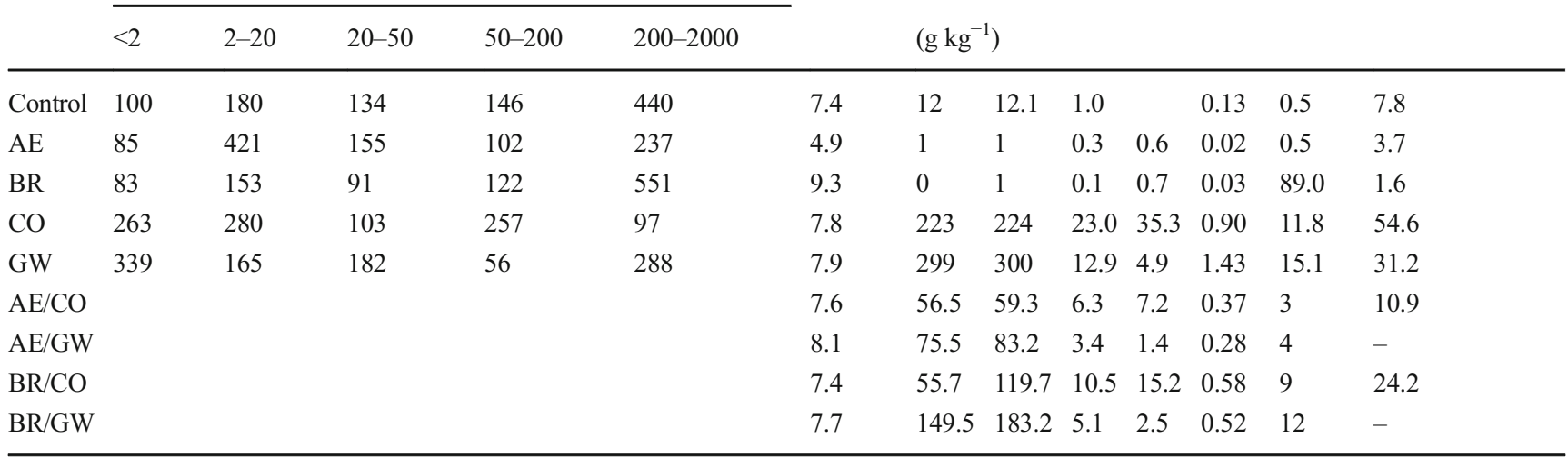

mechanical breakdown test to characterize the resistance of pre-wetted aggregates (Le Bissonnais 1996). The fast and slow wetting tests were conducted on dried aggregates, and the mechanical breakdown was done on aggregates wetted with ethanol before immersion in water. After a test, the samples were transferred to a set of six sieves $(2,1,0.5,0.2,0.1$, $0.05 \mathrm{~mm}$ ). For each test, the mean weight diameter (MWD), that is, the sum of the mass fraction recovered from each sieve multiplied by the average aperture between two adjacent sieves, was calculated and expressed in millimeters. Three replicates were made for each test, and the subsequent results were presented as the averages of replicates, associated with their root-mean-square deviation.

\subsection{Chemical analyses}

The $\mathrm{pH}$ of the soil solution was measured after suspension of $10 \mathrm{~g}$ of ground air-dried sample in 0.051 water (NF ISO 10390, AFNOR 1994). Total concentrations of carbon and nitrogen were determined by dry combustion $\left(1800^{\circ} \mathrm{C}\right)$ using an elemental analyzer (ThermoQuest ${ }^{\circledR}$ device), according to the standard NF ISO 10694 (AFNOR 1995). Soil available phosphorus $\left(\mathrm{P}_{\mathrm{Olsen}}\right)$ was determined according to Olsen's method (Olsen 1956) described in the NF ISO 11263 standard. This parameter gives a good indication of the amount of phytoavailable P. A sample of $2.5 \mathrm{~g}$ of soil crushed to $2 \mathrm{~mm}$ is suspended in a reagent consisting of $\mathrm{NaHCO}_{3}$ at $0.5 \mathrm{~mol} \mathrm{l}^{-1}$ buffered to $\mathrm{pH} 8.5$ with $\mathrm{NaOH}$ in an extraction ratio of $1 / 20$ $(w / v)$. The analysis of $\mathrm{P}$ was done by spectrocolorimetry at $825 \mathrm{~nm}$ after color development of a phosphomolybdic complex. Phosphorus concentration in the plant tissues was measured in the aerial parts of the plants. Plant tissues were ground in an agate mortar to particle sizes smaller than $250 \mu \mathrm{m}$. The powder obtained was mineralized with concentrated nitric acid $\left(\mathrm{HNO}_{3} 69 \%\right)$ and then heated at $80^{\circ} \mathrm{C}$ for $24 \mathrm{~h}$. Finally, the samples were submitted to an attack of hydrogen peroxide $\left(30 \% \mathrm{H}_{2} \mathrm{O}_{2}\right)$ for $6 \mathrm{~h}$. The filtered solutions were analyzed by atomic absorption spectrometry ICP-AES to determine the $\mathrm{P}$ content.

\subsection{Organic matter analysis}

For the compost and the green waste, the organic $\mathrm{C}$ mineralization was measured under controlled laboratory conditions at each date (after 1, 2, 3, 7, 10, 14, 21 28, 35, 42, 50, 59, 72, 86 , and 98 days and then every 2 weeks until the 187th day), for the four mixtures, on three replicates per treatment with the method adapted from the standard XP U44-163 (VidalBeaudet et al. 2012). Fresh samples (equivalent to $50 \mathrm{~g}$ of dry sample) were incubated for a long-term period: 190 days, in 2-1 hermetic glass jars at a constant temperature $\left(28^{\circ} \mathrm{C}\right)$ and constant humidity (field capacity). Mineral $\mathrm{N}\left(\mathrm{KNO}_{3} 1 \mathrm{~g}\right.$ $\mathrm{N}^{-1}$ ) was added at the beginning of the incubations at a sufficient level for biomass activity: $50 \mathrm{mg} \mathrm{N} \mathrm{kg}^{-1}$ per sample. Released $\mathrm{CO}_{2}$ was trapped in $\mathrm{NaOH}\left(0.5 \mathrm{~mol} \mathrm{l}^{-1}\right)$. $\mathrm{BaCl}_{2}$ was added to precipitate carbonates $\left(\mathrm{Na}_{2} \mathrm{CO}_{3}\right)$, and the remaining $\mathrm{NaOH}$ was back-titrated with $\mathrm{HCl}\left(0.25 \mathrm{~mol} \mathrm{l}^{-1}\right)$. Carbon mineralization in the mixtures was calculated from the differences between $\mathrm{CO}_{2}-\mathrm{C}$ produced in the mixtures and $\mathrm{CO}_{2}-\mathrm{C}$ produced in the control treatment. We assumed that $\mathrm{C}$ mineralization in the control was the same with and without exogenous organic matter addition and that exogenous organic matter did not modify soil organic matter degradation (Niklasch and Joergensen 2001). The cumulated mineralized $\mathrm{C}$ of all the treatments was expressed as grams of $\mathrm{CO}_{2}-\mathrm{C}$ per kilogram of total dry mass as compared to the $\mathrm{C}$ contents measured in containers over time.

A morpho-analytical study with a transmission electron microscope (TEM, Philips CM20, $180 \mathrm{kV}$ ) on organic wastes (GW and $\mathrm{CO}$ ) was made on samples dispersed in water and deposited on a grid. The observed particles were subsequently determined with an energy-dispersive X-ray microanalysis (EDX). The morpho-analytical study was to assess the availability of the main fertilizer elements present in the 
technogenic materials. EDX analysis determined the elemental composition of nutrients from the measurement made with a diode $\mathrm{Si}$ of photon energies emitted by the region of the sample bombarded by the electron beam.

\subsection{Statistical analysis}

The R software (version 3.0.1) was used to test for normality of data distribution by the Kolmogorov-Smirnov test and/or Shapiro-Wilk tests. If normality was verified, one-way analysis of variance was performed by Tukey tests with $p<0.05$ as the significance level. If there was no normal distribution, non-parametric tests were used (Kruskal-Wallis). A principal component analysis (PCA) of some data was completed with $R$ (Pearson, $\alpha=5 \%$ ).

\section{Results}

\subsection{Biomass production and $\mathrm{pH}$}

Fifty-five days after sowing, the dry biomass productions of ryegrass (fresh mass dried at $65{ }^{\circ} \mathrm{C}$ during $48 \mathrm{~h}$ ) were the highest for $\mathrm{AE} / \mathrm{CO}$ and $\mathrm{BR} / \mathrm{CO}$ (5.29 and $4.67 \mathrm{~g}$, respectively), medium for the control (2.8 g), and the lowest for AE/GW and $\mathrm{BR} / \mathrm{GW}(0.21$ and $0.11 \mathrm{~g}$, respectively) $(n=4 ; p<0.05)$ (Fig. 1). We observed the same type of results for rape: a very low aerial biomass for the mixtures with $\mathrm{GW}(0.08$ and $0.03 \mathrm{~g}$ for $\mathrm{AE} / \mathrm{GW}$ and $\mathrm{BR} / \mathrm{GW}$, respectively), a medium production for the control $(0.69 \mathrm{~g})$, and the best plant development with $\mathrm{CO}$ (0.96 and $2.54 \mathrm{~g}$ for $\mathrm{AE} / \mathrm{CO}$ and $\mathrm{BR} / \mathrm{CO}$, respectively).

At the beginning of the experiment, the $\mathrm{pH}$ values were very slightly acidic for the control, $\mathrm{AE} / \mathrm{CO}, \mathrm{BR} /$ $\mathrm{CO}$, and $\mathrm{BR} / \mathrm{GW}$ and were 7.4, 7.6, 7.4, and 7.7 respectively, which were appropriate values for plant development (Table 1). Only the $\mathrm{AE} / \mathrm{GW}$ mixture presented an alkaline $\mathrm{pH}$ of 8.1 . Between $\mathrm{t} 0$ and $\mathrm{t55}$, in bare soil, $\mathrm{pH}$ increased from +0.4 units for $\mathrm{AE} / \mathrm{CO}, \mathrm{AE} / \mathrm{GW}$, and $\mathrm{BR} /$ $\mathrm{GW}$; by +0.3 units for the control; and by +0.1 units for $\mathrm{BR} / \mathrm{CO}$. With ryegrass, $\mathrm{pH}$ increased by +0.1 units for $\mathrm{BR} / \mathrm{GW}$, +0.2 units for $\mathrm{AE} / \mathrm{CO}$, +0.4 units for the control, and +0.7 units for $\mathrm{AE} / \mathrm{GW}$ and decreased slightly by -0.1 units for $\mathrm{BR} / \mathrm{CO}$. With rape, the $\mathrm{pH}$ decreased significantly in mixtures containing $\mathrm{CO}$ by -0.2 and -0.4 units in $\mathrm{BR} / \mathrm{CO}$ and $\mathrm{AE} / \mathrm{CO}$, respectively, stayed the same for $\mathrm{BR} / \mathrm{GW}$, and increased by +0.3 units in the control and +0.5 units in $\mathrm{AE} / \mathrm{GW}$ (Fig. 2). Among all the treatments, the $\mathrm{AE} / \mathrm{GW}$ mixture reached the highest value of $\mathrm{pH}$ ( 8.5 on bare soil and rape, 8.7 on ryegrass) which could be problematic for plant development.

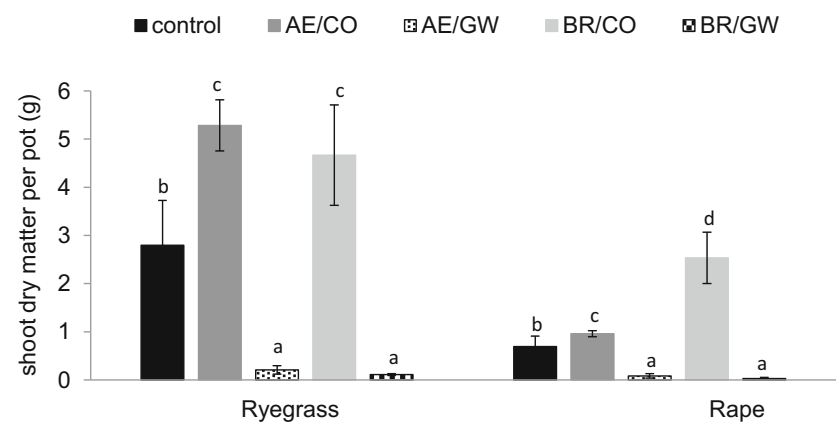

Fig. 1 Shoot dry matter per pot of ryegrass and rape collected 55 days after sowing. Values followed by the same letter within a mixture or control soil and among treatments are not significantly different (statistical significance determined at $p<0.05$ according to Tukey's HSD mean separation test and vertical bars represent standard error of the mean of four replicates)

\subsection{Aggregate stability}

The type of organic matter played a major role in the formation of stable aggregates for all mixtures compared to the control (Fig. 3). The addition of CO did not have any effect on aggregate formation compared to the control. Aggregates formed in AE/CO were unstable (Le Bissonnais 1996) as in the control soil or totally absent in BR/CO. In contrast, GW allowed the formation of very stable aggregates (Le Bissonnais 1996) as well as with AE and BR (MWD 2.72 and $2.52 \mathrm{~mm}$, respectively).

We measured the effect of roots on the stability of the aggregates formed for each mixture and the bare soil (BS) (Fig. 3). The ranking positions of aggregate stability were the same in cultivated pots as in bare pots. Ryegrass had a significant effect $(p<0.05)$ on the structural stability of the control soil compared to the bare soil modality. Rape had a significant effect on the stability of the AE/GW aggregates. For mixtures $\mathrm{AE} / \mathrm{CO}$ and $\mathrm{BR} / \mathrm{GW}$, there were no significant differences between the bare soil, ryegrass, and rape treatments.

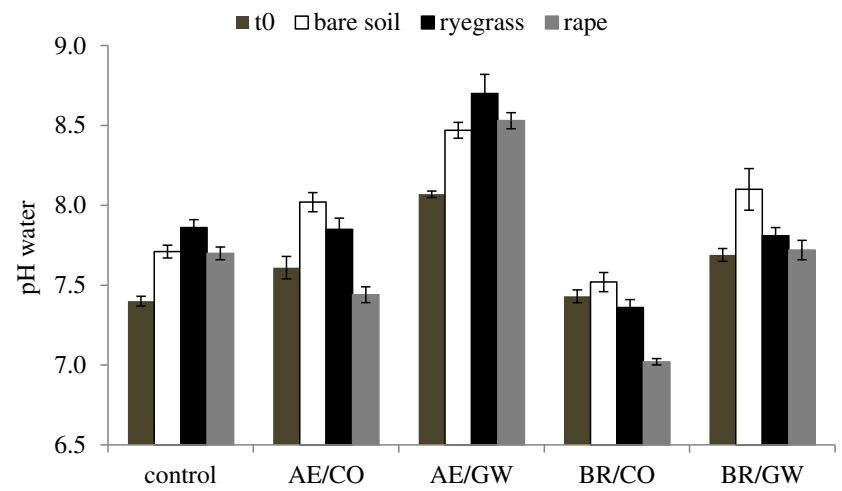

Fig. 2 Evolution of mixtures and control soil $\mathrm{pH}$ at $\mathrm{t} 0$ and $\mathrm{t} 55$ for the bare soil, ryegrass, and rape treatments. Vertical bars represent standard errors of the mean of four replicates 


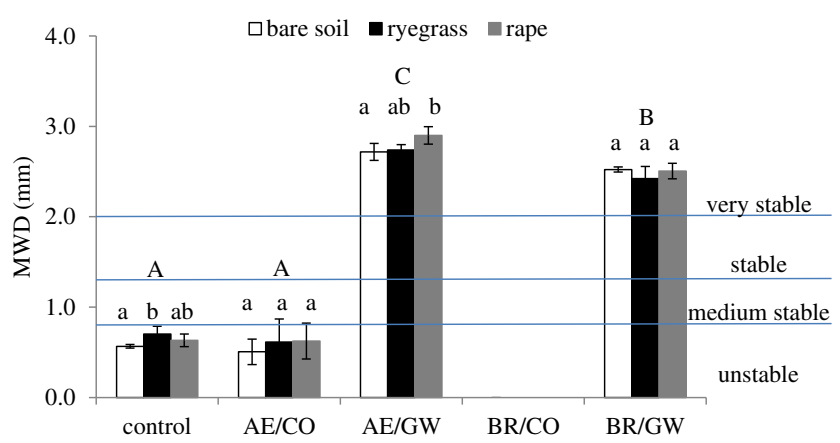

Fig. 3 Effect of organic matter and soil construction modalities on mean weight diameter (MWD) measured with the slow wetting test on aggregates of 3.15-5 mm collected from bare soil, ryegrass, and rape pots after 55 days in controlled conditions. Values followed by a different uppercase letter among a mixture or control soil are significantly different. Values followed by a different lowercase letter within a mixture or control soil and among treatments are significantly different (statistical significance determined at $p<0.05$ according to Tukey's HSD mean separation test and vertical bars represent standard error of the mean of four replicates)

\subsection{Organic matter characteristic}

We observed two mineralization rates of $\mathrm{C}$ in relation to the nature of the organic material used for soil construction. The mineralization of organic carbon $\mathrm{C}-\mathrm{CO}_{2}$ after 190 days was $2.67 \mathrm{~g} \mathrm{~kg}^{-1}$ of total organic carbon for $\mathrm{AE} / \mathrm{GW}$ and BR/GW and $0.8 \mathrm{~g} \mathrm{~kg}^{-1}$ for $\mathrm{AE} / \mathrm{CO}$ and $\mathrm{BR} / \mathrm{CO}$. That was in line with the $\mathrm{C} / \mathrm{N}$ ratio of the organic wastes: 29.1 and 35.9 for $\mathrm{AE} / \mathrm{GW}$ and $\mathrm{BR} / \mathrm{GW}$, respectively, and 9.6 and 10.5 for $\mathrm{AE} / \mathrm{CO}$ and $\mathrm{BR} / \mathrm{CO}$, respectively.

Transmission electron microscope observations revealed that $\mathrm{CO}$ was constituted of highly transformed vegetal organic matter that demonstrated the advanced maturity of the product. Images showed a great number of bacteria spores, which explained the latent bacterial potential of the organic component of CO (Fig. 4a). Elementary microanalysis showed that $\mathrm{N}$ and $\mathrm{P}$ were associated with stable organic matter and microbial residues in $\mathrm{CO}$ and that these elements were little available. GW was constituted of wood and foliar residues that undergo a rapid degradation process. It contained many active and alive bacteria and fungi that colonized the vegetal residues (Fig. 4b). In GW, N and P were located in labile organic matter and microbial residues and had a rapid mobilization associated to high availability.

\subsection{Phosphorus content in the soils}

In the initial state, the total $\mathrm{P}$ content $\left(\mathrm{P}_{\text {tot }}\right)$ in the mixtures mainly depended on the type of the organic matter for the same mineral matter (Table 1), even if the $\mathrm{P}_{\text {tot }}$ content of mineral waste was not so low $\left(0.6\right.$ and $0.7 \mathrm{~g} \mathrm{~kg}^{-1}$ for $\mathrm{AE}$ and $\mathrm{BR}$, respectively). Comparing mixture pairs, those with $\mathrm{CO}$ showed higher $\mathrm{P}$ concentrations (7.2 and $15.2 \mathrm{~g} \mathrm{~kg}^{-1}$ for $\mathrm{AE} / \mathrm{CO}$ and $\mathrm{BR} / \mathrm{CO}$, respectively) than did mixtures with $\mathrm{GW}$
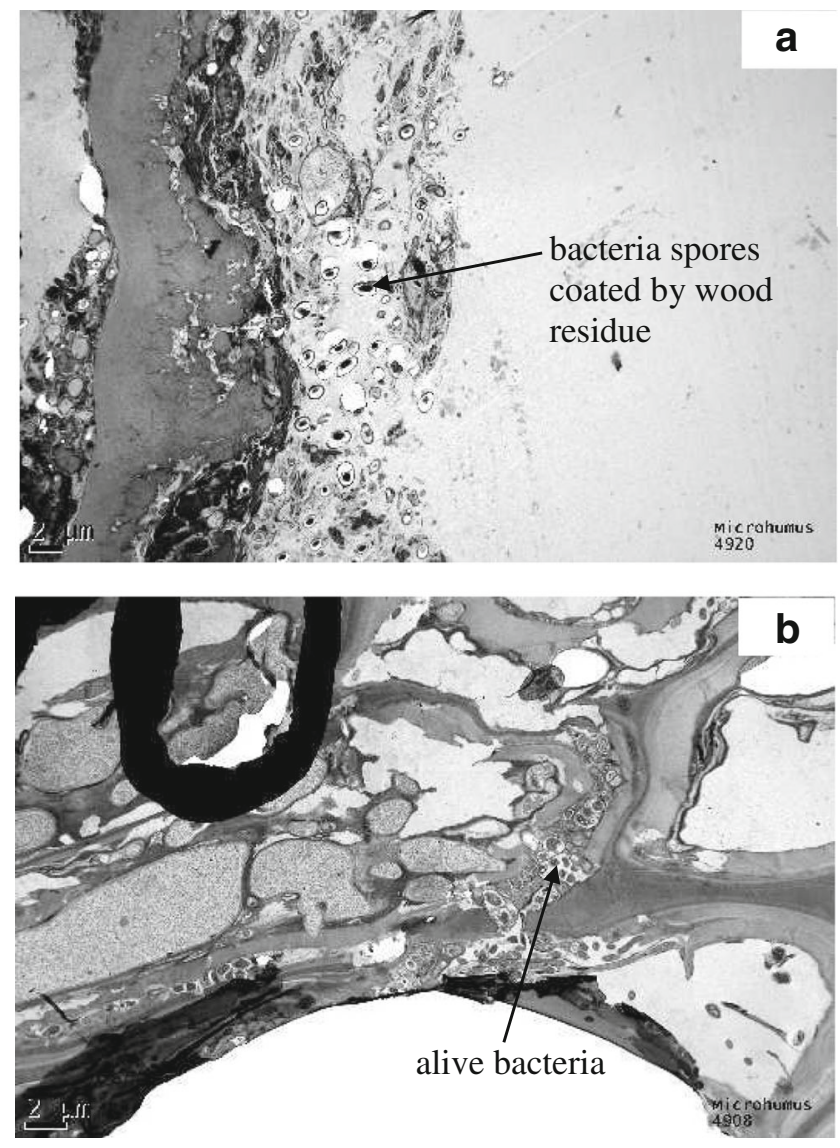

Fig. 4 Images of bacteria spores of $\mathrm{CO}$ coated by wood residue (a) and of alive bacteria of GW (b) obtained by TEM

(1.4 and $2.5 \mathrm{~g} \mathrm{~kg}^{-1}$ for $\mathrm{AE} / \mathrm{GW}$ and $\mathrm{BR} / \mathrm{GW}$, respectively). The $\mathrm{P}_{\text {tot }}$ values were twice as high in mixtures with $\mathrm{BR}$ as in those with AE, since the mass content of organic matter was twice as high for BR compared to AE. Before culture, the concentrations of available $\mathrm{P}_{\text {Olsen }}$ were also higher in mixtures with $\mathrm{CO}\left(0.37\right.$ and $0.58 \mathrm{~g} \mathrm{~kg}^{-1}$ for $\mathrm{AE} / \mathrm{CO}$ and $\mathrm{BR} / \mathrm{CO}$, respectively) than in mixtures with $\mathrm{GW}\left(0.28\right.$ and $0.52 \mathrm{~g} \mathrm{~kg}^{-1}$ for $\mathrm{AE} / \mathrm{GW}$ and $\mathrm{BR} / \mathrm{GW}$, respectively) and the control $\left(0.13 \mathrm{~g} \mathrm{~kg}^{-1}\right)$ (Table 1$)$. For all the mixtures and the control, $\mathrm{P}_{\text {Olsen }}$ contents were higher than the medium value for French natural soils which is $0.05 \mathrm{~g} \mathrm{~kg}^{-1}$ (Jolivet et al. 2006) and constituted a great offer of potentially available $\mathrm{P}$ for the plants. At the end of the experiment, in the bare pots, $\mathrm{P}_{\text {Olsen }}$ contents increased slightly in all the mixtures and the control over time (from 0.13 to $0.17 \mathrm{~g} \mathrm{~kg}^{-1}$ for the control, from 0.37 to $0.38 \mathrm{~g} \mathrm{~kg}^{-1}$ for $\mathrm{AE} / \mathrm{CO}$, from 0.58 to $0.66 \mathrm{~g} \mathrm{~kg}^{-1}$ for $\mathrm{BR} /$ $\mathrm{CO}$, and from 0.52 to $0.65 \mathrm{~g} \mathrm{~kg}^{-1}$ for BR/GW), except for AE/ $\mathrm{GW}$, for which the $\mathrm{P}_{\text {Olsen }}$ content decreased (from 0.28 to $0.21 \mathrm{~g} \mathrm{~kg}^{-1}$ ) (Fig. 5). The influence of the type of the organic material on the status of $\mathrm{P}_{\text {Olsen }}$ was studied after 55 days (Fig. 5), and we observed that $P_{\text {Olsen }}$ was significantly higher in the mixtures with BR than in the mixtures with $\mathrm{AE}$ and the control soil. We measured the effect of plant growth on $\mathrm{P}_{\text {Olsen }}$ contents in each mixture and the control soil (Fig. 5). The 


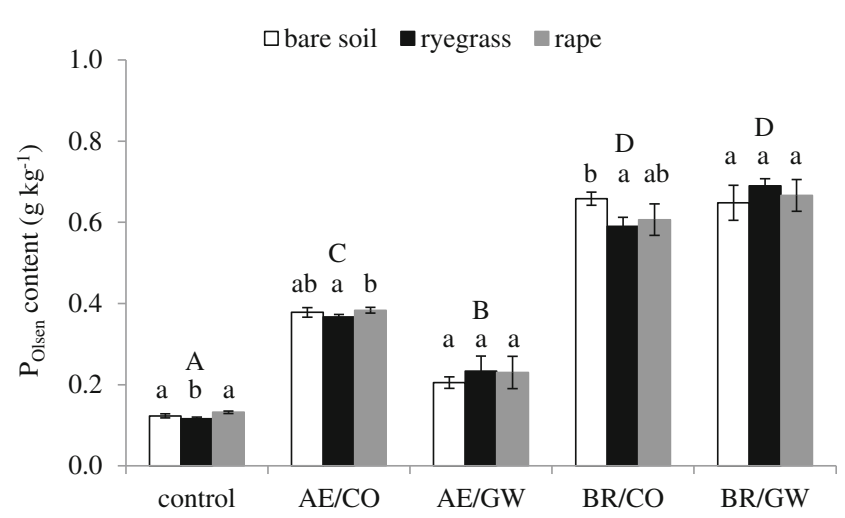

Fig. 5 Effect of organic matter and soil construction modalities on $\mathrm{P}_{\mathrm{Olsen}}$ in bare soil, ryegrass, and rape pots after 55 days in controlled conditions. Values followed by a different uppercase letter among a mixture or control soil are significantly different. Values followed by a different lowercase letter within a mixture or control soil and among treatments are significantly different (statistical significance determined at $p<0.05$ according to Tukey's HSD mean separation test and vertical bars represent standard error of the mean of four replicates)

ranking positions of available $\mathrm{P}$ were the same in cultivated pots as in bare pots. There were no significant differences between the bare soil, ryegrass, and rape treatments on the $\mathrm{P}_{\text {Olsen }}$ contents of the control soil.

\subsection{Phosphorus transfer into the plant}

The mixtures with the highest initial concentrations of available $\mathrm{P}$ did not allow the largest $\mathrm{P}$ uptake by plants (Fig. 6). After 55 days of ryegrass culture, the accumulation of $P$ in the aerial parts for the mixture $\mathrm{AE} / \mathrm{CO}\left(2.89 \mathrm{~g} \mathrm{~kg}^{-1}\right)$ was similar to that measured on $\mathrm{BR} / \mathrm{CO}\left(2.96 \mathrm{~g} \mathrm{~kg}^{-1}\right)$. The AE/GW mixture, which had a twofold smaller $\mathrm{P}_{\text {Olsen }}$ content than the BR/GW mixture, allowed greater $\mathrm{P}$ accumulation $\left(2.07 \mathrm{~g} \mathrm{~kg}^{-1}\right)$ in the shoots of ryegrass than did the BR/GW mixture $\left(1.41 \mathrm{~g} \mathrm{~kg}^{-1}\right)$. In the shoots of rape, the highest concentration of $\mathrm{P}$ (4.21 $\mathrm{g} \mathrm{kg}^{-1}$ ) was obtained with the $\mathrm{AE} / \mathrm{CO}$ mixture. In $\mathrm{AE} /$ $\mathrm{GW}$ and $\mathrm{BR} / \mathrm{CO}$, the concentrations were significantly lower with 3.44 and $3.17 \mathrm{~g} \mathrm{~kg}^{-1}$, respectively. Plants grown on the $\mathrm{BR} / \mathrm{GW}$ mixture have taken up the lowest $\mathrm{P}$ concentrations $\left(2.39 \mathrm{~g} \mathrm{~kg}^{-1}\right)$, which were lower even than that of the control $\left(2.80 \mathrm{~g} \mathrm{~kg}^{-1}\right)$.

The ratio of $\mathrm{P}$ concentration in shoots and the initial $\mathrm{P}_{\text {tot }}$ content were compared for each mixture (Table 2). Rape accumulated systematically more $\mathrm{P}$ than did ryegrass, and these proportions were higher than the ratio of available $\mathrm{P}$ and total $\mathrm{P}$ at $\mathrm{t} 0$ for all the $\mathrm{AE} / \mathrm{CO}$ and $\mathrm{AE} / \mathrm{GW}$ mixtures. In GW mixtures, ryegrass and rape plants respectively accumulated 14.76

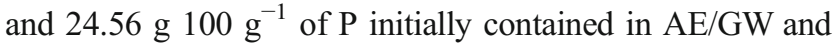

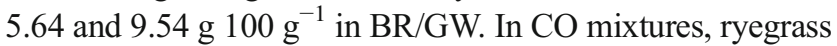
and rape plants respectively accumulated 4.01 and

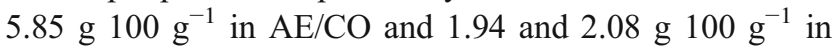
$\mathrm{BR} / \mathrm{CO}$.

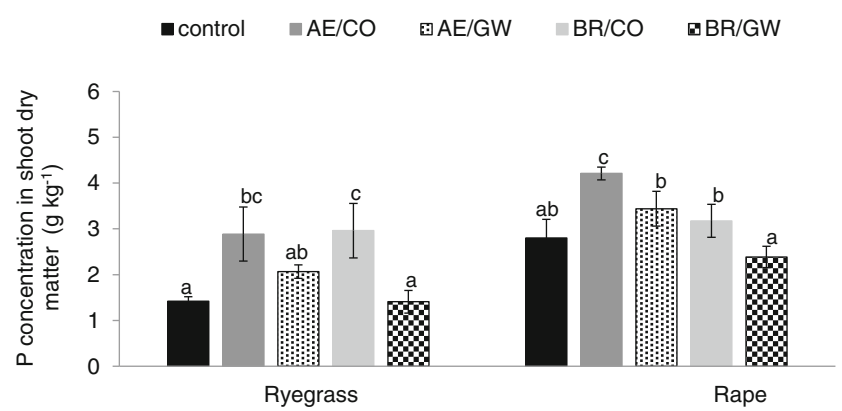

Fig. 6 Phosphorus concentration in shoot dry matter per pot of ryegrass and rape after 55 days of growth in controlled conditions. Values followed by a different lowercase letter within a treatment and among mixtures or control soil are significantly different (statistical significance determined at $p>0.05$ according to Tukey's HSD mean separation test and vertical bars represent standard error of the mean of four replicates)

\section{Discussion}

\subsection{Aggregation factors of waste materials}

Our results showed that stable macroaggregate formation $(3.15-5 \mathrm{~mm})$ was possible by mixing two technogenic materials. The life of an aggregate is relatively short, i.e., from 38 to 95 days for macroaggregates $>200 \mu \mathrm{m}$ (Plante and McGill 2002) and about 88 days for the aggregates between 50 and $200 \mu \mathrm{m}$ (De Gryze et al. 2006). Consequently, the pot experiment lasting a few weeks allowed an initial approach to the stabilization of the waste materials. We evaluated two pedogenetic factors of aggregation formation: the anthropogenic factor related to the selection and mixing of the wastes and the biological factor related to the action of the plant roots.

The nature of the organic matter and inorganic matter plays a major role in the formation of aggregates. In our work, we found significant differences between the aggregate stability promoted by $\mathrm{CO}$ and $\mathrm{GW}$ for a given mineral waste (Fig. 3). Oades (1984) showed that the nature of organic matter strongly influenced aggregation. Annabi et al. (2007) studied the impact on the aggregation of different organic materials added to a loamy soil, by comparing urban composts of different types and different maturities. They demonstrated that both mature and immature composts caused differing aggregate stabilization kinetics. The differences observed between aggregate stability of the mixtures $\mathrm{AE} / \mathrm{GW}$ and $\mathrm{AE} / \mathrm{CO}$ were due to the high biological potential of the immature GW (high C/N ratios, 29.1 and 35.9 for $\mathrm{AE} / \mathrm{GW}$ and $\mathrm{BR} / \mathrm{GW}$, respectively) compared to the lower one of mature $\mathrm{CO}$ (low $\mathrm{C} / \mathrm{N}$ ratios, 9.6 and 10.5 for $\mathrm{AE} / \mathrm{CO}$ and $\mathrm{BR} / \mathrm{CO}$, respectively). In addition to the quality of the materials involved, the role of microbial populations - activity and presence of $\mathrm{C}$ easily usable by microorganisms - is also decisive in the soil aggregation processes (Bossuyt et al. 2001; Annabi et al. 2007). Fungal biomass can represent $66 \%$ of the microbial biomass (Denef et al. 2001) and is generally better correlated with the formation of stable aggregates than the total biomass (Cosentino et al. 
Table 2 Ratio of initial $\mathrm{P}_{\text {Olsen }}$ on the initial $\mathrm{P}_{\text {tot }}$ content and ratio of $\mathrm{P}_{\text {accumulated }}$ in the aerial parts of plant (ryegrass and rape) on the initial $\mathrm{P}_{\text {tot }}$ content for each mixture

\begin{tabular}{|c|c|c|c|c|c|}
\hline & \multirow{2}{*}{$\begin{array}{l}P_{\text {total per pot }} \\
\text { At t } 0 \\
\text { (g) }\end{array}$} & \multirow{2}{*}{$\begin{array}{l}\text { POlsen per pot } \\
\text { At t0 } \\
\text { (g) }\end{array}$} & \multirow{2}{*}{$\begin{array}{l}\mathrm{P}_{\text {Olsen }} / \mathrm{P}_{\text {total }} \\
\text { At t0 } \\
\left(\mathrm{g} 100 \mathrm{~g}^{-1}\right)\end{array}$} & \multicolumn{2}{|c|}{$\mathrm{P}_{\text {accumulated }} / \mathrm{P}_{\text {total }}$} \\
\hline & & & & $\begin{array}{l}\text { Ryegrass } \\
\left(\mathrm{g} 100 \mathrm{~g}^{-1}\right)\end{array}$ & $\begin{array}{l}\text { Rape } \\
\left(\mathrm{g} 100 \mathrm{~g}^{-1}\right)\end{array}$ \\
\hline Control & & 0.36 & & & \\
\hline $\mathrm{AE} / \mathrm{CO}$ & 14.4 & 0.74 & 5.14 & 4.01 & 5.85 \\
\hline $\mathrm{AE} / \mathrm{GW}$ & 2.5 & 0.50 & 20.00 & 14.76 & 24.56 \\
\hline $\mathrm{BR} / \mathrm{CO}$ & 30.4 & 1.16 & 3.82 & 1.95 & 2.09 \\
\hline $\mathrm{BR} / \mathrm{GW}$ & 3 & 0.62 & 20.80 & 5.64 & 9.55 \\
\hline
\end{tabular}

2006). The large and active microbial biomass of GW was qualified by TEM images and explained the strong aggregation observed in mixtures with GW versus with $\mathrm{CO}$.

Following a 55-day culture cycle, our results showed that (i) the stabilization of aggregate mixtures was significantly increased in bare soil and after cultivating ryegrass or rape and (ii) the influence of plant growth was significant for the control soil and the $\mathrm{AE} / \mathrm{GW}$ mixture and there was no influence for the other mixtures (Fig. 3). Many authors have highlighted the positive influence of roots on the stabilization of soil macroaggregates (Tisdall and Oades 1982; Morel et al. 1991; Pojasok and Kay 1990; Angers and Caron 1998; Lesturgez et al. 2004). Jangorzo et al. (2013) showed an effect of the roots on the increased aggregate number in constructed Technosols, but without checking their stability to water. This suggests that, similarly to what happens in agricultural soils, plants growing on mixtures of technogenic materials promote the stabilization of aggregates through the release of root exudates. In our study, the development of plant biomass was low in mixtures and control soil, which is why we have few differences in structural stability between the bare soil treatment and planted treatments. Aggregate stability is mainly related to the development of fungal flora (Chenu and Cosentino 2011) which we have observed through TEM. Fungal development was observed on the TEM image and visually in the pots containing GW at the end of experiment. The qualification and quantification of fungi contained in the organic material to be recycled appear then as a path to explore, in order to select the most effective organic wastes in terms of contribution to structural stability.

\subsection{Phosphorus content in technogenic mixtures}

Due to the low $\mathrm{P}$ release rate by the weathering of rocks, $\mathrm{P}$ is present at very low concentrations in the solution of unfertilized soils (Frossard et al. 2004). Organic forms of P (carbon skeleton of biological structures) are not available for the roots and can represent 30 to $65 \%$ of the total P (Harrison 1987). These forms must first be hydrolyzed by phosphatase enzymes produced by the roots, bacteria, and fungi to release the inorganic $\mathrm{P}$, which can be then taken up by the roots (Richardson 2001). Phosphorus availability for roots in soils results from complex physical-chemical, biochemical, and biological processes that control its concentration in solution (Frossard et al. 2004). In our study, $\mathrm{P}_{\text {Olsen }}$ concentrations of technogenic mixtures varied over time between 0.2 and $0.7 \mathrm{~g} \mathrm{~kg}^{-1}$. These concentrations were about 100 times higher than those found in agricultural soils, which are more in the range of 0.003 to $0.008 \mathrm{~g} \mathrm{~kg}^{-1}$ (Zhang 2004). In this study, Zhang (2004) showed that the concentrations of $\mathrm{P}_{\text {Olsen }}$ increased along a gradient of increasing anthropization, with maximum concentrations reaching $0.174 \mathrm{~g} \mathrm{~kg}^{-1}$. In a work published by Joimel et al. (2016), the lowest median concentration of $\mathrm{P}_{\text {Olsen }}$ was measured in forest soils $\left(0.006 \mathrm{~g} \mathrm{~kg}^{-1}\right)$, while the highest median occurred in garden topsoils $(0.183$ $\%$ ). The median value for urban and industrial topsoils was $0.045 \mathrm{~g} \mathrm{~kg}^{-1}$. The concentrations measured by us are quite close to those found in urban soils and represented a great $\mathrm{P}$ offer for plants. The $\mathrm{pH}$ and the concentrations of metal ions (e.g., $\mathrm{Ca}, \mathrm{Fe}, \mathrm{Al}$ ), which can precipitate with phosphate ions in the soil solution, influence the availability of $\mathrm{P}$ (Hinsinger 2001; Devau et al. 2009). Thus, the P in a mineral form may precipitate in various forms of calcium phosphates (e.g., monocalcium phosphates, dicalcium phosphate dihydrates) (Tunesi et al. 1999). To explain $\mathrm{P}_{\text {Olsen }}$ changes in our experiment, we compared $\mathrm{pH}$ values at the beginning ( $\mathrm{t} 0$ ) and at the end (t55) (Fig. 2). The decreasing $\mathrm{pH}$ in mixtures with $\mathrm{CO}$ should allow the dissolution of immobilized $\mathrm{P}$ and a higher $\mathrm{P}$ uptake by plants. Phosphorus concentrations found in the shoots of rape after 55 days $\left(3.44 \mathrm{~g} \mathrm{~kg}^{-1}\right.$ for AE/GW and $4.21 \mathrm{~g} \mathrm{~kg}^{-1}$ for $\mathrm{AE} / \mathrm{CO}$ ) were comparable to that found in Brassica oleracea after 8 weeks on soils fertilized with $2.5 \mathrm{~g}$ $\mathrm{P} \mathrm{kg}^{-1}$, which was $5.1 \mathrm{~g} \mathrm{~kg}^{-1}$ (Sharma et al. 2007). For the Poaceae, wheat, or barley, Gallet et al. (2003) found similar P concentrations of 3.6 to $4.3 \mathrm{~g} \mathrm{~kg}^{-1}$, which are slightly higher than our values $\left(2.89 \mathrm{~g} \mathrm{~kg}^{-1}\right.$ for $\mathrm{AE} / \mathrm{CO}$ and $2.96 \mathrm{~g} \mathrm{~kg}^{-1}$ for $\mathrm{BR} / \mathrm{CO}$ ). This means that despite the high concentrations of $\mathrm{P}$ in the constructed Technosols with $\mathrm{CO}$, the shoot tissues accumulated less than the initial available $\mathrm{P}$, and this result suggested that $\mathrm{P}$ uptake is limited due to deficient uptake of 
Fig. 7 Principal component analysis of physical parameters (MWD), chemical parameters $\left(\mathrm{pH}, \mathrm{P}_{\text {Olsen }}, \mathrm{N}_{\text {tot }}, \mathrm{C}_{\text {tot }}\right)$, and biological parameters (dry aerial biomass) measured after 55 days for the treatments for bare sol (BS), ryegrass (RG), and rape (RA) for all the mixtures and the control

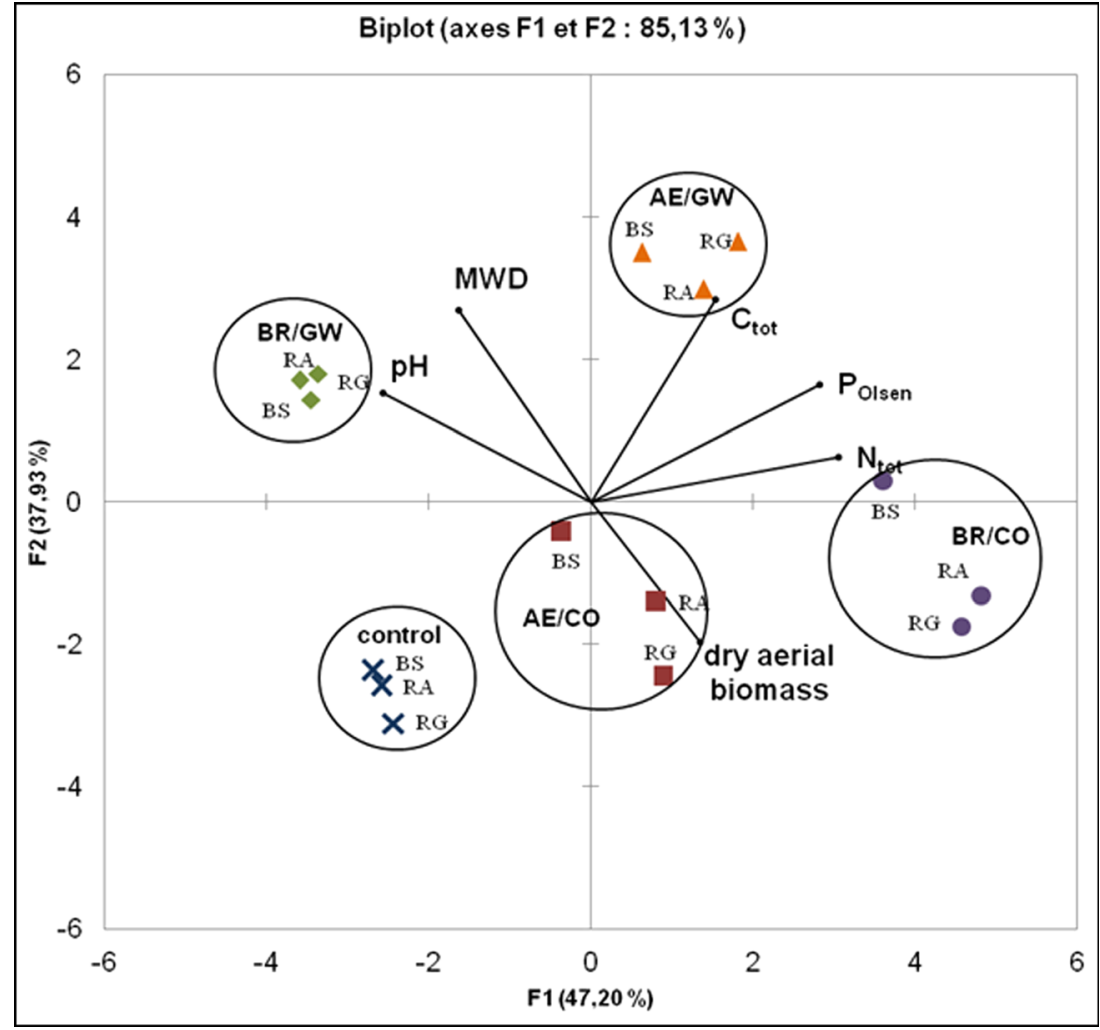

nutrient. Yet, in the mixtures with GW, the P accumulated by the cultures after 55 days was higher than the initial total $\mathrm{P}$ pool and seemed very high in proportion to the biomass produced.

\subsection{Interaction between aggregation intensity and $P$ release}

The anthropogenic factor (organic waste selection for the pedological engineering) was dominant in influencing the aggregation process and the mobilization of nutrients. Needless to say, at this stage only assumptions can be made to explain this strong influence. The major hypothesis is that the stabilization

Table 3 Correlation coefficients $(r)$ between physical parameters (MWD), chemical parameters $\left(\mathrm{pH}, \mathrm{P}_{\text {Olsen }}, \mathrm{N}_{\text {tot }}, \mathrm{C}_{\text {tot }}\right.$ ), and biological parameters (dry aerial biomass) of the principal component analysis

\begin{tabular}{lllllll}
\hline Parameter & MWD & $\mathrm{P}_{\text {Olsen }}$ & $\mathrm{pH}$ & $\mathrm{C}_{\text {tot }}$ & $\mathrm{N}_{\text {tot }}$ & Dry biomass \\
\hline MWD & $\mathbf{1}$ & & & & & \\
$\mathrm{P}_{\text {Olsen }}$ & -0.03 & $\mathbf{1}$ & & & & \\
$\mathrm{pH}$ & $\mathbf{0 . 7 8}$ & -0.44 & $\mathbf{1}$ & & & \\
$\mathrm{C}_{\text {tot }}$ & 0.51 & $\mathbf{0 . 8 4}$ & 0.04 & $\mathbf{1}$ & & \\
$\mathrm{N}_{\text {tot }}$ & -0.32 & $\mathbf{0 . 8 6}$ & $\mathbf{- 0 . 5 5}$ & $\mathbf{0 . 5 6}$ & $\mathbf{1}$ & \\
Dry biomass & $\mathbf{- 0 . 5 2}$ & 0.04 & -0.42 & -0.24 & 0.26 & $\mathbf{1}$ \\
\hline
\end{tabular}

Values in bold are significant correlations at the 0.05 probability level of formed aggregates and the release of nutrients are conditioned by the potential degradation of organic waste. We studied the interactions that exist between all the parameters measured in a constructed Technosol-plant system: aerial biomass, aggregate stability (MWD), $\mathrm{pH}$, and nutrient contents $\left(\mathrm{P}_{\mathrm{Olsen}}\right.$, $\mathrm{N}_{\text {tot }}, \mathrm{C}_{\text {tot }}$ ). A principal component analysis showed that the mixtures had little in common (Fig. 7). AE/GW mixtures were essentially characterized by the MWD parameter and their higher $\mathrm{pH}$ values (the $\mathrm{BR} / \mathrm{GW}$ mixtures by the MWD and the $\mathrm{C}_{\text {tot }}$ content). BR/CO mixtures were essentially characterized by $\mathrm{P}_{\text {Olsen }}$ concentration, high $\mathrm{N}_{\text {tot }}$ content, and allowing the highest biomass production. $\mathrm{AE} / \mathrm{CO}$ mixtures were quite close to the origin and were consequently poorly represented. Low $\mathrm{N}_{\text {tot }}$ and $\mathrm{P}_{\text {Olsen }}$ concentrations characterized the control soil. The aggregation process (MWD) and $\mathrm{P}_{\text {Olsen }}$ were independent and had a very low correlation $r=-0.03$ (Table 3). This result was consistent with the study by Wang et al. (2001) showing that $\mathrm{P}$ uptake was greater in those soils rich in small aggregates than in other soils dominated by macroaggregates. Increasing the contact area between the particles promoted the exchange, the creation of bonds, and adsorption/desorption at the surface of the particles. BR/CO had the lowest MWD, with all aggregates lower than $3 \mathrm{~mm}$ and the highest $\mathrm{P}_{\text {Olsen }}$ content. MWD was closely correlated to $\mathrm{pH}(r=0.78)$ and $\mathrm{P}_{\text {Olsen }}$ had a strong correlation to $\mathrm{C}_{\text {tot }}$ and $\mathrm{N}_{\text {tot }}: 0.84$ and 0.86 , respectively (Table 3). MWD had a negative correlation with shoots $(r=-0.52)$, and the GW mixtures had the lowest biomass 
production. In mixtures with $\mathrm{GW}$, the rapid degradation of organic matter led to an enhanced $\mathrm{N}$ requirement, in order to meet the intense microbial activity. $\mathrm{N}$ was taken from the reserves of the mixture, which became insufficient for the development of the plant due to the competition with microorganisms.

Interactions between aggregation and the release of $\mathrm{P}$ are complex and related to the characteristics of the organic waste. Microelemental analysis (TEM-EDX) of CO revealed a high total reserve of $\mathrm{N}$ and $\mathrm{P}$ associated with stable organic matter as well as with microbial residues. According to their location in stable organic matter component, phytoavailable elements will be effective in the medium and long term, so the resource is more sustainable. In GW, TEM-EDX revealed the location of $\mathrm{N}$ and $\mathrm{P}$ in walls and cells of the organic waste biodegraded during processing and in microbial residues. Perhaps, $\mathrm{P}$ could become very rapidly phytoavailable for microorganisms and plants due to microbial activity.

\section{Conclusions}

We have confirmed that it is possible to construct fertile Technosols from selected urban wastes. In controlled conditions after 55 days of culture, mixtures of technogenic materials have enabled a high production of plant biomass. These mixtures had a higher fertility than did an agricultural soil with available $\mathrm{P}$ contents ranging from 0.28 to $0.58 \mathrm{~g} \mathrm{~kg}^{-1}$ and nearly 10 times higher than the average concentrations of all French soils (Jolivet et al. 2006). Constructed Technosols also showed the occurrence of early pedogenetic processes involved in the formation of aggregates. Those aggregates are more or less stable, and their stability depended heavily on the type of the organic matter selected for mixtures (high stability with green wastes and low stability with sludge and green waste compost).

These early stages of pedogenesis, linked to the organic matter type, influence the physico-chemical fertility of the constructed Technosols. The mixtures with GW had rapid organic matter degradation, which allowed the formation of macroaggregates, a very rapid release of $\mathrm{P}$, but poor biomass development induced by competition for $\mathrm{N}$, between those microorganisms involved in organic matter and plant degradation. The mixtures with $\mathrm{CO}$ had small aggregates (diameter $<1 \mathrm{~mm}$ ), a gradual release of $\mathrm{P}$, and allowed good plant development and high $\mathrm{P}$ accumulation in shoots.

The constructed Technosols exhibit a great offer of $\mathrm{P}$ for plants. The early aggregation processes in these soils could facilitate the release of nutrients such as P. These soils constructed with technogenic materials could ensure essential functions for urban areas such as (i) recovery and recycling of waste produced by man, (ii) biomass production, and (iii) nutrient reserve and releases.
Acknowledgments This work was supported by the ADEME (the French Environmental Agency, SITERRE research project) and conducted within the framework of the GISFI (www.gisfi.fr). We thank the French-German academic exchange program PROCOPE (DAAD and 358 CAMPUS FRANCE) and the German science foundation (DFG, FOR 1736) for financial support. The authors wish to thank the technical staff of LSE (Adeline Bouchard, Stéphane Colin), of GISFI (Rémi Baldo, Lucas Charrois), of EPHor (Y. Barraud-Roussel, S. Delepine-Bourgeois, and C. Mazzega), and all the partners involved in the SITERRE program for their substantial help. Some data and images used have been obtained within the framework of Microhumus company.

\section{References}

AFNOR (1994) NF ISO 10390. Qualité du sol—Détermination du pH. AFNOR, Paris

AFNOR (1995) NF ISO 10694. Qualité du sol—Dosage du carbone organique et du carbone total par combustion sèche (analyse élémentaire). AFNOR, Paris

Angers DA, Caron J (1998) Plant-induced changes in soil structure: processes and feedbacks. Biogeochem 42:55-72

Angers DA, Edwards LM, Sanderson JB, Bissonnette N (1999) Soil organic matter quality and aggregate stability under eight potato cropping sequences in a fine sandy loam of Prince Edward Island. Can J Soil Sci 79:411-417

Annabi M, Houot S, Francou F, Poitrenaud M, Le Bissonnais Y (2007) Soil aggregate stability improvement with urban composts of different maturities. Soil Sci Soc Am J 71:413-423

Badin AL, Mederel G, Bechet B, Borschneck D, Delolme C (2009) Study of the aggregation of the surface layer of Technosols from stormwater infiltration basins using grain size analyses with laser diffractometry. Geoderma 153:163-171

Barber SA, Silberbush M (1984) Plant root morphology and nutrient uptake. ASA Spec Pub Root Nut Water Influx Plant Growth 49: 65-87

Bossuyt H, Denef K, Six J, Frey SD, Merckx R, Paustian K (2001) Influence of microbial populations and residue quality on aggregate stability. Appl Soil Ecol 16:195-208

CEN (1999) EN 13040. Soil improvers and growing media. Sample preparation for chemical and physical tests, determination of dry matter content, moisture content and laboratory compacted bulk density. European Committee for Standardization, Bruxelles

Chenu C, Cosentino D (2011) Microbial regulation of soil structural dynamics. In: Ritz K, Young I (eds) Architecture and biology of soils: life in inner space. CAB International, Wallingford, pp 37-69

Chenu C, Le Bissonnais Y, Arrouays D (2000) Organic matter influence on clay wettability and soil aggregate stability. Soil Sci Soc Am J 64: 1479-1486

Cordell D, Drangert J-O, White S (2009) The story of phosphorus: global food security and food for thought. Glob Environ Chang 19(2):292305

Cosentino D, Chenu C, Le Bissonnais Y (2006) Aggregate stability and microbial community dynamics under drying-wetting cycles in a silt loam soil. Soil Biol Biochem 38:2053-2062

De Gryze S, Jassogne L, Six J, Bossuyt H, Wevers M, Merckx R (2006) Pore structure changes during decomposition of fresh residue: $\mathrm{x}$-ray tomography analyses. Geoderma 134:82-96

Denef K, Six J, Bossuyt H, Frey SD, Elliott ET, Merckx R, Paustian K (2001) Influence of dry-wet cycles on the interrelationship between aggregate, particulate organic matter, and microbial community dynamics. Soil Biol Biochem 33:1599-1611

Devau N, Le Cadre E, Hinsinger P, Jaillard B, Gerard F (2009) Soil pH controls the environmental availability of phosphorus: experimental 
and mechanistic modelling approaches. Appl Geochem 24:21632174

El Khalil H, Schwartz C, Elhamiani O, Kubiniok J, Morel JL, Boularbah A (2008) Contribution of technic materials to the mobile fraction of metals in urban soils in Marrakech (Morocco). J Soils Sediment 8: $17-22$

Frossard E, Skrabal P, Sinaj S, Bangerter F, Traoré O (2002) Form and exchangeability of inorganic phosphate in composted solid organic wastes. Nutr Cycl Agroecosys 62:103-113

Frossard E, Julien P, Neyroud JA, Sinaj S (2004) Le phosphore dans les sols. Etat de la situation en Suisse. Cahier de l'environnement $n^{\circ} 368$. Office fédéral de l'environnement, des forêts et du paysage, Berne

Gallet A, Flisch R, Ryser JP, Frossard E, Sinaj S (2003) Effect of phosphate fertilization on crop yield and soil phosphorus status. J Plant Nutr Soil Sci 166:568-578

Grinsted MJ, Hedley MJ, White RE, Nye PH (1982) Plant-induced changes in the rhizosphere of rape (Brassica Napus Var. Emerald) seedlings. New Phytol 91:19-29

Grosbellet C, Vidal-Beaudet L, Caubel V, Charpentier S (2011) Improvement of soil structure formation by evolution of coarse organic matter. Geoderma 162:27-38

Harrison AF (1987) Soil organic phosphorus: a review of world literature, CAB International Wallingford, UK. http://library.wur.nl/ WebQuery/clc/164150. Accessed 19 November 2013

Hedley MJ, Nye PH, White RE (1983) Plant-induced changes in the rhizosphere of rape (Brassica Napus Var. Emerald) seedlings. IV. The effect of rhizosphere phosphorus status on the $\mathrm{pH}$, phosphatase activity and depletion of soil phosphorus fractions in the rhizosphere and on the cation-anion balance in the plants. New Phytol 95:69-82

Hinsinger P (2001) Bioavailability of soil inorganic P in the rhizosphere as affected by root-induced chemical changes: a review. Plant Soil 237:173-195

Hoffland E, Findenegg GR, Nelemans JA (1989) Solubilization of rock phosphate by rape. Plant Soil 113:155-160

Howard JL, Olszewska D (2011) Pedogenesis, geochemical forms of heavy metals, and artifact weathering in an urban soil chronosequence, Detroit, Michigan. Environ Pollut 159:754-761

Huot H (2013) Formation, fonctionnement et évolution d'un Technosol sur des boues sidérurgiques. PhD Université de Lorraine, Nancy

Jangorzo N, Schwartz C, Watteau F (2013) Image analysis of soil thin sections for a non-destructive quantification of aggregation in the early stages of pedogenesis. Eur J Soil Sci 65:485-498

Jastrow JD (1996) Soil aggregate formation and the accrual of particulate and mineral-associated organic matter. Soil Biol Biochem 28:665676

Jimenez EI (1993) City refuse compost as a phosphorus source to overcome the P-fixation capacity of sesquioxide-rich soils. Plant Soil 148:115-127

Johnson AF, Vietor DM, Rouquette FM, Haby VA (2004) Fate of phosphorus in dairy wastewater and poultry litter applied on grassland. J Environ Qual 33:735-739

Joimel S, Cortet J, Jolivet CC, Saby NPA, Chenot ED, Branchu P, Consalès JN, Lefort C, Morel JL, Schwartz C (2016) Physicochemical characteristics of topsoil for contrasted forest, agricultural, urban and industrial land uses in France. Sci Total Environ 545-546: $40-47$

Jolivet C, Boulonne L, Ratié C (2006) Manuel du réseau de Mesures de la Qualité des Sols. Unité InfoSol INRA, Orléans

Le Bissonnais Y (1996) Aggregate stability and assessment of soil crustability and erodibility: I. Theory and methodology. Eur J Soil Sci 47:425-437

Lehmann A, Stahr K (2007) Nature and significance of anthropogenic urban soils. J Soils Sediment 7:247-260
Lesturgez G, Poss R, Hartmann C, Bourdon E, Noble A, Ratana-Anupap $S$ (2004) Roots of Stylosanthes hamate create macropores in the compact layer of sandy soil. Plant Soil 260:101-109

Monsérié MF, Watteau F, Villemin G, Ouvrard S, Morel JL (2009) Technosol genesis: identification of organo-mineral associations in a young Technosol derived from coking plant waste materials. J Soils Sediment 9:537-546

Morel JL, Habib L, Plantureux S, Guckert A (1991) Influence of maize root mucilage on soil aggregate stability. Plant Soil 136:111-119

Morel JL, Chenu C, Lorenz K (2015) Ecosystem services provided by soils of urban, industrial, traffic, mining, and military areas (SUITMAs). J Soil Sediment 15:1659-1666

Nehls T, Rokia S, Mekiffer B, Schwartz C, Wessolek G (2013) Contribution of bricks to urban soil properties. J Soils Sediment 13:575-584

Nehls T, Schwartz C, Kim KHJ, Kaupenjohann M, Wessolek G, Morel JL (2015) Letter to the editor: phyto-p-mining - secondary urban green extracts phosphorus from soils constructed of secondary resources for p recycling. J Soils Sediment 15:1667-1674

Niklasch H, Joergensen RG (2001) Decomposition of peat, biogenic municipal waste compost, and shrub/grass compost added in different rates to a silt loam. J Plant Nutr Soil Sci 164:365-369

Nziguheba G (1998) Soil phosphorus fractions and adsorption as affected by organic and inorganic sources. Plant Soil 198(2):159-168

Oades JM (1984) Soil organic matter and structural stability: mechanisms and implications for management. Plant Soil 76:319-337

Olsen SRW (1956) A method to determine a phosphorus adsorption maximum of soils as measured by the Langmuir isotherm. Soil Sci Soc Am J 21:144

Pey $\mathrm{B}$ (2010) Contribution à la faune du sol au fonctionnement et à l'évolution des Technosols. PhD Université de Lorraine, Nancy

Plante AF, McGill WB (2002) Soil aggregate dynamics and the retention of organic matter in laboratory-incubated soil with differing simulated tillage frequencies. Soil Till Res 66:79-92

Pojasok T, Kay BD (1990) Effect of root exudates from corn and bromegrass on soil structural stability. Can J Soil Sci 70:351-362

Rausch C, Bucher M (2002) Molecular mechanisms of phosphate transport in plants. Planta 216:23-37

Richardson AE (2001) Prospects for using soil microorganisms to improve the acquisition of phosphorus by plants. Funct Plant Biol 28: 897-906

Rokia S, Séré G, Schwartz C, Deeb M, Fournier F, Nehls T, Damas O, Vidal-Beaudet L (2014) Modelling agronomic properties of Technosols constructed with urban wastes. Waste Manag 34:21552162

Séré G, Schwartz C, Ouvrard S, Renat JC, Watteau F, Villemin G, Morel JL (2010) Early pedogenic evolution of constructed Technosols. J Soils Sediment 10:1246-1254

Sharma NC, Starnes DL, Sahi SV (2007) Phytoextraction of excess soil phosphorus. Environ Pollut 146:120-127

Tisdall JM, Oades JM (1982) Organic matter and water-stable aggregates in soils. J Soil Sci 33:141-163

Tunesi S, Poggi V, Gessa C (1999) Phosphate adsorption and precipitation in calcareous soils: the role of calcium ions in solution and carbonate minerals. Nutr Cycl Agroecosys 53:219-227

Vidal-Beaudet L, Grosbellet C, Forget-Caubel V, Charpentier S (2012) Modelling long term carbon dynamics in soil reconstituted with high quantities of organic matter. Eur J Soil Sci 63:787-797

Wang X, Yost RS, Linquist BA (2001) Soil aggregate size affects phosphorus desorption from highly weathered soils and plant growth. Soil Sci Soc Am J 65:139-146

Zhang MK (2004) Phosphorus accumulation in soils along an urbanrural land use gradient in Hangzhou, Southeast China. Commun Soil Sci Plan 35:819-833 